\title{
Is there any effect of smoking status on severity and mortality of hospitalized patients with COVID-19 pneumonia?
}

\author{
Efsun Gonca \\ UĞUR CHOUSEIN ${ }^{1}$ (ID) \\ Mustafa ÇÖRTÜK ${ }^{\mathbf{1}}$ (ID) \\ Halit CINARKA ${ }^{\mathbf{1}}$ (ID) \\ Elif TANRIVERDi ${ }^{1}$ (ID) \\ Demet TURAN ${ }^{1}$ (ID) \\ Binnaz Zeynep \\ YILDIRIM ${ }^{1}$ \\ Celal Buğra SEZEN ${ }^{\mathbf{1}}($ ID) \\ Mehmet Akif ÖZGÜL ${ }^{\mathbf{1}}$ (ID)
}

\author{
${ }^{1}$ Clinic of Chest Diseases, University of Health Sciences, Yedikule \\ Chest Diseases and Thoracic Surgery Training and Research Hospital, \\ Istanbul, Turkey \\ ${ }^{1}$ Sağlık Bilimleri Üniversitesi, Yedikule Gögüs Hastalıkları ve Gögüs Cerrahisi \\ Ĕgitim ve Araștırma Hastanesi, Göğüs Hastalıkları Kliniği, İstanbul, Türkiye
}

\begin{abstract}
Is there any effect of smoking status on severity and mortality of hospitalized patients with COVID-19 pneumonia?

Introduction: The Severe Acute Respiratory Syndrome (SARS-CoV-2) virus, which emerged from China and spread all over the world, has affected the world in every aspect and will do so in the foreseeable future. This study was carried out to investigate the possible aggravating effect of smoking on the prognosis of patients with COVID-19 pneumonia presenting with pulmonary involvement.
\end{abstract}

Materials and Methods: 114 adult patients who received inpatient treatment in our clinic with the diagnosis of COVID-19 pneumonia between 11 March 2020 and 30 April 2020 were retrospectively included in the study; in particular, they were evaluated in terms of smoking history, severity of disease, need for NIMV and ICU admission, and mortality during their hospitalization.

Cite this article as: Uğur Chousein $E G$, Çörtük $M$ CInarka $H$, Tanriverdi $E$, Turan $D$, Yıldırım $B Z$, et al. Is there any effect of smoking status on severity and mortality of hospitalized patients with COVID-19 pneumonia? Tuberk Toraks 2020:68(4):371-378.

Yazışma Adresi (Address for Correspondence)

\section{Dr. Efsun Gonca UĞUR CHOUSEIN}

Sağlık Bilimleri Üniversitesi,

Yedikule Göğüs Hastalıkları ve

Göğüs Cerrahisi Eğitim ve Araștırma Hastanesi, Göğüs Hastalıkları Kliniği,

ISTANBUL - TÜRKIYE

e-mail: efsungoncachousein@yahoo.com

\footnotetext{
CCopyright 2020 by Tuberculosis and Thorax.
}

Available on-line at www.tuberktoraks.org.com
Results: The mean age of the 114 patients hospitalized with COVID-19 pneumonia was $51.14 \pm 14.97$ (range 16-81), and 77 (67.5\%) were male. Of the patients, $19(15.9 \%)$ were active smokers, 23 were ex-smokers $(20.1 \%), 72$ $(63.1 \%)$ non-smokers. The effect of smoking on the severity of the disease, length of hospitalization, need for non-invasive mechanical ventilation (NIMV) and intensive care unit (ICU) admission and mortality were not statistically significant.

Conclusion: The rate of active smoking in patients hospitalized with COVID19 is lower than the population average. In this study, no correlation was observed between smoking status and the severity, prognosis and mortality of the disease. Further studies with larger number of patients and case series are needed to better elucidate the relationship between smoking and COVID-19 and the pathophysiologic mechanisms of the effects of smoking on the natural history of COVID-19 pneumonia.

Key words: Smoking; COVID-19 pneumonia; severity; mortality 
ÖZ

\section{COVID-19 pnömonisi ile yatan hastalarda sigara öyküsünün hastalık şiddetli ve mortalitesi üzerinde bir etkisi var mı?}

Giriş: Çin'de ortaya çıkarak tüm dünyaya yayılan Severe acute respiratory syndrome (SARS-CoV-2) virüsü, her açıdan dünyayı etkilemiştir ve daha da etkileyecek gibi görünmektedir. Asemptomatik bir klinikten, yoğun bakım ihtiyacı ve ölüm ile sonuçlanabilen alt solunum yolu enfeksiyonu tablosuna kadar uzanan farklı ağırlıkta tablolara yol açmıştır. Bu çalışma primer olarak akciğeri etkileyen yol açtığı COVID-19 hastalığında sigaranın prognoz üzerindeki olası ağırlaştırıcı etkisini araştırmak amaçlı yapılmıştır.

Materyal ve Metod: 11 Mart 2020 ve 30 Nisan 2020 arasında kliniğimizde COVID-19 pnömonisi tanısı ile yatarak tedavi gören, 114 erişkin hasta çalışmaya alınmış ve retrospektif olarak; özellikle sigara öyküleri, hastane başvurusu öncesi semptomları ve süresi, hastalığın ciddiyet derecesi, yatışları boyunca gerek duyulan NIMV, ICU ihtiyaçları ve mortalite açısından değerlendirilmiştr.

Bulgular: COVID-19 tanısı ile yatan 114 hastanın yaş ortalaması $51.14 \pm 14.97$ (range 16-81), ve 77 (\%67.5)'si erkekti. Hastaların 19'u (\%15.9) aktif sigara içici, 23'ü ex-smoker (\%20.1) 72'si (\%63.1) hiç sigara içmemiş idi. Bu oranlar aktif sigara içici ve ex-smokerlar için toplum ortalamasından düşüktü. Sigara içiciliğin hastalığın hafif ya da ağır olması üzerinde, hastanede kalış süresi, non invazif mekanik ventilasyon (NIMV), yoğun bakım ünitesi (YBÜ) ve mortalite üzerinde etkisi istatistiksel olarak anlamlı değildi.

Sonuç: COVID-19 tanısı ile yatan hastalarda aktif sigara içme oranı toplum ortalamasından düşüktür. Sigara içiciliğin; hastalığın hafif ya da ağır olması üzerinde etkili olmadı̆̆ı, prognostik göstergeler ve mortalite ile ilişkili olmadığı görülmüştür. Sigara ve COVID-19 ilişkisi ve hastalık üzerindeki etkisi için daha büyük hasta sayıları ile ve mekanizmalar açııından daha ileri çalışmalara ve vaka serilerine ihtiyaç vardır.

Anahtar kelimeler: Sigara içiciliği; COVID-19 pnömonisi; hastalı̆̆ın ciddiyeti; mortalite

\section{INTRODUCTION}

A new viral agent, which emerged from Wuhan City of China and spread all over the world and identified as Severe Acute Respiratory Syndrome (SARS-Cov-2) virus in December 2019, spread globally and was accepted as a pandemic by World Health Organisation (WHO). It can cause diseases ranging in severity from asymptomatic infection to fulminant pulmonary involvement and even death $(1,2)$.

While COVID-19 has been affecting humans for less than a year, smoking and smoking-related diseases, especially pulmonary diseases are among the leading causes of mortality, morbidity and treatment costs for centuries with a prevalence of active smoking over the age of 15 in the world was $18.7 \%$ and $31.2 \%$ in Turkish population according to the last updated data of World Health Organisation (WHO) and Turkish Ministry of Health, General Directorate of Public Health's $(3,4)$. The prevalence of smoking related pulmonary and extrapulmonary diseases in a community is directly correlated to the prevalence of smoking in the same community. Additionally, smoking is a predisposing and aggravating factor for diseases such as bacterial and viral pneumonias (5).

Studies on COVID-19 pneumonia since December 2019 have intriguingly reported conflicting results regarding smoking and COVID-19 association. Some studies report a detrimental effect while others state that active smoking protects against this infection and even propose nicotine bands tried as treatment (5-8). We aimed to retrospectively evaluate prevalence of smoking in our patients hospitalized with COVID-19 pneumonia and its effect on the prognosis of the disease.

\section{MATERIALS and METHODS}

\section{Study Population}

114 patients hospitalized and discharged between 11 March and 30 April 2020 with the diagnosis of COVID-19 pneumonia were retrospectively evaluated. Digital data and file notes were scanned for demographic characteristics, contact history, complaints at the time of admission, the time from the onset of complaints to hospitalization, length of hospital stay (LOS), smoking history, swab PCR results, all biochemical and hematological parameters, chest $\mathrm{x}$-rays and thorax computed tomographs (CT), treatment protocols, oxygen, non-invasive mechanical ventilation (NIMV) and mechanical ventilation (MV) needs. Patients needing NIMV were followed up in the wards, and those requiring MV in the intensive care unit (ICU). Mortality was defined as that during hospitalization or in the first 30 days after discharge.

Patients admitted with COVID-19 pneumonia were divided into 2 severity groups according to the regularly updated guideline of the Scientific Board of the Ministry of Health of the Republic of Turkey. Oxygen saturation in room air $<90 \%$, respiratory rate $\geq 30 / \mathrm{min}$, widespread pneumonic infiltrations on chest $X$-rays 
and/or thorax computed tomography (CT), or acute organ dysfunction were defined as "severe disease". Treatment was commenced according to guidelines. Hydroxychloroquine and antiviral agents such as favipiravir and oseltamivir were used empirically, and antibiotics were added in patients whose clinical, radiological findings and history were compatible with COVID-19 pneumonia, pending swab PCR results.

Patients were divided according to their smoking history into 3 groups: active smokers, ex-smokers and non/never-smokers.

Length of stay (LOS), need for non-invasive mechanical ventilation (NIMV) or mechanical ventilation (MV) [intensive care unit (ICU) admission] and mortality of patients in the severe and non-severe groups were analysed to control for the effect of smoking status on the prognosis.

The research was carried out in accordance with the Declaration of Helsinki. Written consent was obtained from all patients at the time of hospitalization. Additionally, a novel consent form regarding COVID19 was also obtained. Ethics committee approvals were obtained from the Ethic Committee of Health Science University (46418926-050.03.04/ 20/156) and the Ethic Committee of Republic of Turkey Ministry of Health (2020-04-30T18_13_46).

\section{Statistical Analysis}

Continuous variables were presented as mean \pm standard deviation and discrete variables were presented as frequencies. Demographics and clinical characteristics of the patients such as age and hospital stay duration were tested for normal distribution using the Kolmogorov-Smirnov test. T-test was used to compare group means for these variables, the chi-square test was used to compare between the two groups and Kruskal Wallis test for testing relationships between numerical variables of three groups. Analyses were performed using the SPSS software program (Version 22, SPSS Inc., Chicago, IL, USA). A p-value $<0.05$ was considered significant.

\section{RESULTS}

114 patients who were hospitalized and treated with COVID-19 pneumonia were included in the study. Their mean age was $51.14 \pm 14.97$ (range 16-81) and $77(67.5 \%)$ were male. 19 patients were in the active smoker group, 23 were ex-smokers and 72 were never smoked. Their mean ages were $51.5 \pm 15.1$ years, $57.2 \pm 10.3$ years and $49.1 \pm 15.8$ years respectively according to smoking status. $57(50 \%)$ were PCR(-) negative, 54 (47.4\%) PCR(+) positive, and in $3(2.6 \%)$ patients PCR results were unobtainable.

Most common complaints at admission were cough (68.4\%) and shortness of breath (54.4\%). Both were most common in active smokers, followed by ex-smokers and non-smokers (shortness of breath in $63 \%, 56.5 \%$ and $54.1 \%$, and cough in $78 \%, 65.5 \%$ and $65 \%$, respectively). There was no significant difference between the groups in terms of symptoms.

The mean duration of symptoms from onset to admission was $8.21 \pm 6.71$ days in the smoker group, 9.69 \pm 7.36 in the ex-smoker group and $7.62 \pm 4.41$ days in the non-smoker group, with no statistically significant difference between the 3 groups.

The demographic characteristics and general prognostic indicators of the patients according to their smoking history is shown in Table 1.

$71 / 114(62.3 \%)$ patients had non-severe and 43/114 $(37.7 \%)$ had severe disease. These groups were not statistically significantly different in gender distribution $(p=0.103)$. Patients with severe disease were at more advanced age than patients with non-severe disease $(p=0.012)$. The percentage of active smokers, ex-smokers, and non-smokers were 16,9\%, 16,9\% and $66.2 \%$ in the non-severe group, and $16.3 \%$, $25.6 \%$ and $58.1 \%$ in the severe group respectively. There was no statistical difference between the groups according to the smoking history (Table 2).

Pulmonary comorbidities such as chronic obstructive pulmonary disease (COPD), asthma, bronchiectasis, tuberculosis, pulmonary tromboembolism and lung cancer were present in \%18.4 of patients and were significantly more often in the active smoker group than the non-smoker group ( $p=0.003$ ) (Table 2).

Length of stay (LOS), need for non invasive mechanical ventilation (NIMV) and intensive care unit (ICU) admission were not significantly different in active smokers in the severe and non severe groups $(p=$ $0.068, p=0.36, p=0.123$ respectively). Among ex-smokers, ICU admission need was significantly increased in the severe disease group $(p=0.014)$ while LOS and NIMV were not significantly different. LOS was significantly longer $(p=0.007)$, need for NIMV $(p=0.001)$ and ICU admission $(p=0.001)$ 
Table 1. Demographic characteristics of the patients according to their smoking history

\begin{tabular}{|c|c|c|c|c|}
\hline & Active smoker & Ex-smoker & Non-smoker & $\mathrm{p}<0.05$ \\
\hline Number of patients ( $\mathrm{n}$ ) & 19 & 23 & 72 & \\
\hline Mean age (years) & $51.5 \pm 15.1$ & $57.2 \pm 10.3$ & $49.1 \pm 15.8$ & 0.076 \\
\hline Gender (male/female) & $14 / 5$ & $21 / 2$ & $42 / 30$ & 0.011 \\
\hline Duration of sypmtoms (days) & $8.21 \pm 6.71$ & $9.69 \pm 7.36$ & $7.62 \pm 4.41$ & 0.526 \\
\hline \multicolumn{5}{|l|}{ Sypmtoms } \\
\hline Cough & $15(78.9 \%)$ & $15(65.2 \%)$ & $47(60.2 \%)$ & 0.344 \\
\hline Dyspnoea & $12(63.1 \%)$ & $13(56.5 \%)$ & $39(54.1 \%)$ & 0.652 \\
\hline Sputum & $2(10.5 \%)$ & $2(8.6 \%)$ & $6(8.3 \%)$ & 0.828 \\
\hline Length of hospital stay (days) & $10.13 \pm 5.09$ & $8.97 \pm 4.56$ & $8.9 \pm 4.5$ & 0.490 \\
\hline Pulmonary comorbidities & $10 / 19(52 \%)$ & $3 / 23(13 \%)$ & $13 / 72(18 \%)$ & 0.003 \\
\hline NIMV need & $1(5.2 \%)$ & $6(26 \%)$ & $11(15.2 \%)$ & 0.180 \\
\hline ICU admission & $2(10 \%)$ & $6(26 \%)$ & $12(16 \%)$ & 0.397 \\
\hline Mortality & $3(15.7 \%)$ & $4(17.3 \%)$ & $9(12.5 \%)$ & 0.817 \\
\hline
\end{tabular}

were significantly increased in non-smokers within the severe disease group compared to the non-severe group. The mortality rate was significantly increased in ex-smokers $(p=0.037)$ and non-smokers $(p=$ $0.001)$ in comparison to active smokers $(p=0.123)$ (Table 2).

The most important mortality risk factors were advanced age, NIMV requirement and severity of the disease while active smoking had no effect on mortality $(\mathrm{p}=0.123)$.

\section{DISCUSSION}

The new COVID-19 pandemic has adversely affected healthcare systems throughout the globe, and caused widespread social and economic disruptions $(6,7)$. Our knowledge about this virus evolves as health providers gain more experience and insight in its pathophysiology and treatment. Our fast evolving knowledge is sometimes marked by conflicting information and opinions.

The relation between COVID-19 and smoking is one of those controversial subjects. Although some studies have found that smoking increased the likelihood of hospitalisation and mortal outcome in COVID-19 pneumonia, some studies have reached opposite results. Meta-analyses of these studies have also reached conflicting results $(8,9)$.

Considering the interaction of smoking, SARS-CoV-2 and lungs at the cellular level studies have shown that smoking affects innate and adaptive immunity and can exacerbate pathogenic immune responses or attenuate immunity. Forsslund et al. have shown that smokers had more CD8+ T cells than CD4+ T cells in bronchoalveolar lavage (BAL) fluid than non-smokers. Another study showed that smokers had less circulating NK cells than non-smokers while numbers of NK cells in BAL appear to increase (10). SARSCov-2 also affects innate and adaptive immunity and causes a significantly higher CD8+ T cells expression, although the ratio of $\mathrm{CD} 4+\mathrm{T}$ cells to $\mathrm{CD} 8+\mathrm{T}$ cells was found to be similar in COVID-19 patients and healthy subjects. Additionally, analysis of BAL fluid revealed an increase in CD8+ T cell. While COVID-19 patients had decreased numbers of NK cells in their circulation, the numbers of NK cells in BAL fluid analysis were increased compared to healthy subjects (11-14). One possible explanation for the relative protective effect of smoking against COVID-19 infection could be the presence of increased numbers of NK or CD8+ T cells in their alveolar spaces in early period. Studies regarding the increased gene expression of angiotensin-converting enzyme 2 (ACE2) in smokers, which acts as a receptor for the SARS-CoV-2, indicate that smoking has a detrimental effect on COVID-19 infection (15). It is currently not clear which mechanism is predominant in the clinical course of the disease.

According to World Health Organisation (WHO) data, the prevalence of active smoking over the age of 15 in the world was $18.7 \%$ by 2020 . The last updated data of the Turkish Ministry of Health, 
Uğur Chousein EG, Çörtük M, Cınarka H, Tanrıverdi E, Turan D, Yıldırım BZ, et al.

Table 2. Factors affecting the severity and mortality of the disease

\begin{tabular}{|c|c|c|c|c|c|}
\hline \multirow[b]{2}{*}{ Variables } & \multicolumn{2}{|c|}{ Non-severe disease } & \multicolumn{2}{|c|}{ Severe disease } & \multirow{2}{*}{$\begin{array}{c}\text { Univariate Analysis } \\
\mathbf{p}<\mathbf{0 . 0 5}\end{array}$} \\
\hline & $\mathbf{n}$ & $\%$ & $\mathbf{n}$ & $\%$ & \\
\hline \multicolumn{6}{|l|}{ Gender } \\
\hline Male & 44 & 62 & 33 & 76.7 & \multirow{2}{*}{0.103} \\
\hline Female & 27 & 38 & 10 & 23.3 & \\
\hline \multicolumn{6}{|l|}{ Age(years) } \\
\hline$($ Year $\pm S t D)$ & \multicolumn{2}{|c|}{$48.25 \pm 14.73$} & \multicolumn{2}{|c|}{$55.90 \pm 14.27$} & 0.012 \\
\hline$>65$ & 61 & 85.9 & 28 & 65.1 & \\
\hline$<65$ & 10 & 14.1 & 15 & 34.9 & 0.009 \\
\hline \multicolumn{6}{|l|}{ Smoking history } \\
\hline Active smoker & 12 & 16.9 & 7 & 16.3 & \multirow{3}{*}{0.527} \\
\hline Ex-smoker & 12 & 16.9 & 11 & 25.6 & \\
\hline Non-smoker & 47 & 66.2 & 25 & 58.1 & \\
\hline \multicolumn{6}{|l|}{ Pulmonary comorbidities } \\
\hline No & 53 & 74.6 & 35 & 81.4 & \multirow[t]{2}{*}{0.405} \\
\hline Yes & 18 & 25.4 & 8 & 18.6 & \\
\hline \multicolumn{6}{|l|}{ Ground glass opacity } \\
\hline Unilateral & 17 & 23.9 & 4 & 9.3 & \multirow[t]{2}{*}{0.050} \\
\hline Bilateral & 54 & 76.1 & 39 & 90.7 & \\
\hline \multicolumn{6}{|l|}{ Active smoker } \\
\hline \multicolumn{6}{|l|}{ NIMV } \\
\hline No & 12 & 100 & 6 & 85.7 & \multirow[t]{2}{*}{0.368} \\
\hline Yes & 0 & 0 & 1 & 14.3 & \\
\hline \multicolumn{6}{|l|}{ ICU } \\
\hline No & 12 & 100 & 5 & 71.4 & \multirow[t]{2}{*}{0.123} \\
\hline Yes & 0 & 0 & 2 & 28.6 & \\
\hline Mortality & & & & & \\
\hline No & 12 & 100 & 5 & 71.4 & 0.123 \\
\hline Yes & 0 & 0 & 2 & 28.5 & \\
\hline Length of hospital stay(days) & & & & & 0.068 \\
\hline Ex-smoker & & & & & \\
\hline NIMV & & & & & \\
\hline No & 11 & 91.7 & 6 & 54.5 & 0.059 \\
\hline Yes & 1 & 8.3 & 5 & 45.5 & \\
\hline ICU & & & & & \\
\hline No & 12 & 100 & 6 & 54.5 & 0.014 \\
\hline Yes & 0 & 0 & 5 & 45.5 & \\
\hline Mortality & & & & & \\
\hline No & 12 & 100 & 7 & 63.6 & 0.037 \\
\hline Yes & 0 & 0 & 4 & 36.3 & \\
\hline Length of hospital stay(days) & & & & & 0.051 \\
\hline Non-smoker & & & & & \\
\hline NIMV & & & & & \\
\hline No & 47 & 100 & 16 & 64 & 0.001 \\
\hline Yes & 0 & 0 & 9 & 36 & \\
\hline $\mathrm{ICU}$ & & & & & \\
\hline No & 47 & 100 & 15 & 60 & 0.001 \\
\hline Yes & 0 & 0 & 10 & 40 & \\
\hline Mortality & & & & & \\
\hline No & 46 & 97.8 & 25 & 75.7 & 0.001 \\
\hline Yes & 1 & 2.1 & 8 & 24.2 & \\
\hline Length of hospital stay(days) & & & & & 0.007 \\
\hline
\end{tabular}


General Directorate of Public Health reported that among people over the age of 15 years the prevalence of active smoking was $31.2 \%$, while ex-smokers constitute $15.2 \%$, and non-smokers $52.8 \%$ of the population $(3,4)$. In a study in France, it was found that the incidence of symptomatic COVID-19 patients was lower than the general French population (16). In our study population the percentage of active smokers was $16.7 \%$, ex-smokers was $20.2 \%$, and non-smokers was $63.2 \%$. It was observed that the percentage of active smokers hospitalized with COVID-19 pnemonia was less than the general active smoking prevalence of both world, French and Turkish society.

Studies on the relation between disease severity and smoking status have reached unexpected results. Zhang et al., in their study of 140 patients, found that the percentage of active smokers, ex-smokers and non-smokers among 58 patients with severe disease were $3.4 \%, 6.9 \%$ and $89.7 \%$ respectively. Among the remaining 82 patients with mild (non-severe) disease there were no active smokers, $3.7 \%$ were ex-smokers and $96.3 \%$ were non-smokers (17). In a large series of 1099 patients by Guan et al., among severe patients $16.9 \%$ were active smokers, $5.2 \%$ were ex-smokers and $77.9 \%$ were non-smokers. Among those with non-severe disease, $11.8 \%$ were active smokers, $1.3 \%$ ex-smokers, $86.9 \%$ non-smokers (18). In our study, the percentages of smokers, ex-smokers and non-smokers was 16.3\%, 25.6\%, and $58.1 \%$ respectively in the severe group and $16.9 \%, 16.9 \%$ and $66.2 \%$ in the non-severe group and were compatible with the numbers given by Zhang et al. and Guan et al.

Observational studies indicated that COVID-19 had a more severe clinical course in the presence of comorbidities. The meta-analysis by Liu at al. has found that pulmonary comorbidities are present in 3\% of COVID-19 patients, that the presence of pulmonary and extrapulmonary morbidities affects disease severity but has no effect on the mortality of the disease. [19] In a meta-analysis by Sanches-Ramirez et al. it was observed that underlying respiratory diseases, specifically chronic obstructive pulmonary disease (COPD) were associated with severe COVID-19 outcomes (20-22). $18.4 \%$ of our study population had pulmonary comorbidities such as COPD, asthma, lung cancer, former existing pulmonary thromboembolism, tuberculosis sequela; the most frequent being asthma in $12.2 \%$ and smoking-related diseases such as chronic obstructive pulmonary disease (COPD) in $4.3 \%$, and lung cancer in $2 \%$. We have similarly found that the presence of pulmonary comorbidities has not effect on the severity of the disease (Table 2).

In a large series of 1099 patients by Guan et al., when poor prognostic indicators such as need for NIMV, ICU admission or a mortal outcome were evaluated; active smokers represented $25.8 \%$, ex-smokers $7.6 \%$ and non-smokers $66.7 \%$ (18). In our study group 19 patients had poor prognostic indicators (need for NIMV, ICU admission or a mortal outcome) $10.5 \%$ of were active smokers, with ex-smokers comprising $31.6 \%$ and non-smokers $57.8 \%$.

In a meta-analysis by Karanasos et al., evaluating the correlation between the severity and mortality of COVID-19 in hospitalized patients and their smoking status, it was stated that active smoking had no association with disease severity (10 studies with 4152 patients; Odds Ratio $[\mathrm{OR}]=1.12,95 \%$ confidence intervals $[\mathrm{Cl}]=0.84-1.50, \mathrm{I}^{2}=38 \%$ ) but any history of smoking modestly increased the risk for the combined end point of disease severity $(O R=1.34,95 \%$ $\mathrm{Cl}=1.07-1.67, \mathrm{I}^{2}=45 \%$ ) In the same meta-analysis, five studies with 838 patients were included and it was found out that smoking was not significantly associated with increased mortality $(\mathrm{OR}=1.45,95 \%$ $\mathrm{Cl}=0.78-2.72, \mathrm{I}^{2}=18 \%$ ) (23). In our study we found no statistically significant difference in poor prognostic indicators such as NIMV need $(p=0.368)$ or ICU admission $(p=0.123)$ or mortal outcome $(p=0.123)$ between non-severe and severe disease groups in patients who were active smokers. We found that ex-smokers were significantly more often admitted to the ICU $(p=0.014)$ and had a mortal outcome $(p=$ 0.037) rates but their need for NIMV was not increased $(p=0.059)$. Non-smokers with severe disease had increased rates of NIMV need and ICU admission and mortality (Table 2).

Although smokers are known to have more severe disease and higher mortality during lower respiratory tract infections especially in some viral pneumonias, we did not find a similar effect during COVID-19 pneumonia (24-26).

Our study has limitations such as being retrospective and single-centered, it nevertheless contributes to the understanding of a very newly defined viral pandemic in the world. 


\section{CONCLUSION}

According to the data obtained in our study, it was observed that the prevalence of active smoking in COVID-19 hospitalized patients was lower than that in the general population and that smoking had no effect on disease severity. It has also been determined that smoking has no effect on length of hospital stay, NIMV and ICU requirement and mortality. The interaction between smoking and COVID-19 will remain uncertain for some time and perhaps will be elucidated when further data will be available about the pathophysiologic relationship between smoking and COVID-19.

Ethical Committee Approval: Approvals for this study were obtained from the Ethical Committee of Health Science University (Decision no: 46418926050.03.04/20/156 Date: 24.04.2020) and the Ethical Committee of Republic of Turkey Ministry of Health (Decision no: 2020-04-30T18_13_46 Date: 01.05.2020).

\section{CONFLICT of INTEREST}

The authors of this study declare that they have no conflict of interest.

\section{AUTHORSHIP CONTRIBUTIONS}

Concept/Design: MC, EGUC

Analysis/Interpretation: CBS

Data Acquisition: DT, ET, EGUC, BZY, MAO, MC

Writting: EGUC, MC

Critical Revision: EGUC, MC, HC

Final Approval: All of authors

\section{REFERENCES}

1. Dai $H$, Zhang $X, X i a$ J, Zhang $T$, Shang $Y$, Huang $R$, et al. High-resolution Chest CT Features and Clinical Characteristics of Patients Infected with COVID-19 in Jiangsu, China. Int J Infect Dis 2020; 95: 106-12.

2. Huang C, Wang Y, Li X, Ren L, Zhao J, Hu Y, et al. Clinical features of patients infected with 2019 novel coronavirus in Wuhan, China. Lancet 2020; 395(10223): 497-506.

3. World Health Organization (WHO). Current cigarette smoking rate-trends in prevalence of tobacco smoking: global level in: Global World report on trends in prevelance of tobacco smoking: 2000-2025: 11-25. WHO.

4. Republic of Turkey Ministry of Health. Public Health Institution of Turkey Department of Combating Tobacco and Substance Addiction. Global Adult Tobacco Survey Turkey Report 2012: 10-12.
5. Winnall WR, Bellew B, Greenhalgh EM, Winstanley MH. Increased susceptibility to infection in smokers. In: Greenhalgh EM, Scoll, MM, Winstanley MH (eds). Tobacco In Australia: Facts And Issues. Melbourne: Cancer Council Victoria; 2020.

6. Nicola M, Alsafi Z, Sohrabi C, Kerwan A, Al-Jabir A, losifidis $C$, et al. The socio-economic implications of the coronavirus and COVID-19 pandemic: a review. Int I Surg 2020; 78: 185-93.

7. Yezli S, Khan A. COVID-19 social distancing in the Kingdom of Saudi Arabia: Bold measures in the face of political, economic, social and religious challenges. Travel Med Infect Dis 2020; 101692.

8. Patanavanich R, Glantz SA. Smoking is associated with COVID-19 progression: a meta-analysis. Nicotine Tob Res 2020; 22(9): 1653-6.

9. Lippi G, Henry BM. Active smoking is not associated with severity of coronavirus disease 2019 (COVID-19). Eur J Intern Med 2020; 75: 107-8.

10. Forsslund H, Mikko M, Karimi R, Grunewald I, Wheelock AM, Wahlstrom J, et al. Distribution of T-cell subsets in BAL fluid of patients with mild to moderate COPD depends on current smoking status and not airway obstruction. Chest 2014; 145: 711-22.

11. Tollerud DJ, Clark JW, Brown LM, Neuland CY, Mann DL, Pankiw-Trost $L K$, et al. Association of cigarette smoking with decreased numbers of circulating natural killer cells. Am Rev Respir Dis 1989; 139(1): 194-8.

12. Ganjia A, Farahani I, Khansarinejada B, Ghazavib A, Mosayebi G. Increased expression of CD8 marker on T-cells in COVID-19 patients. Blood Cells Mol Dis 2020; 83: 102437.

13. Liao M, Liu Y, Yuan J, Wen Y, Xu G, Zhao J, et al. Single-cell landscape of bronchoalveolar immune cells in patients with COVID-19. Nat Med 2020; 26(6): 842-4.

14. García LF. Immune response, inflammation, and the clinical spectrum of COVID-19. Front Immunol 2020; 11 1441 .

15. Cai G, Bossé Y, Xiao F, Kheradmand F, Amos Cl. Tobacco smoking increases the lung gene expression of ACE2, the receptor of SARS-CoV-2. Am J Respir Crit Care Med 2020 Jun 15; 201(12): 1557-9.

16. 16-Miyara M, Tubach F, Pourcher V, Morelot-Panzini C, Pernet J, Haroche J, et al. Low incidence of daily active tobacco smoking in patients with symptomatic COVID-19. Qeios 2020; 1-13.

17. Zhang J, Dong X, Cao Y, Yuan Y, Yang Y, Yan Y, Akdis CA, et al. Clinical characteristics of 140 patients infected with SARS-CoV-2 in Wuhan, China. Allergy 2020; 75: 1730-41.

18. Guan W, Ni Z, Hu Y, Liang W, Ou C, He J, et al. Clinical characteristics of coronavirus disease 2019 in China. N Engl J Med 2020; 382: 1708-20. 
19. Liu H, Chen S, Liu M, Nie H, Lu H. Comorbid chronic diseases are strongly correlated with disease severity among COVID-19 patients: a systematic review and metaanalysis. Aging Dis 2020; 11(3): 668-78.

20. Sanchez-Ramirez DC, Mackey D. Underlying respiratory diseases, specifically COPD, and smoking are associated with severe COVID-19 outcomes: A systematic review and meta-analysis. Respir Med 2020; 171: 106096.

21. Luo J, Rizvi H, Preeshagul IR, Egger IV, Hoyos D, Bandlamudi $C$, et al. COVID-19 in patients with lung cancer. Ann Oncol 2020; 31(10): 1386-96.

22. Leung IM, Niikura $M$, Yang CWT, Sin DD. COVID-19 and COPD. Eur Respir J 2020; 56: 2002108.

23. Karanasos A, Aznaouridis K, Latsios G, Synetos A, Plitaria $S$, Tousoulis D, et al. Impact of smoking status on disease severity and mortality of hospitalized patients with COVID19 infection: a systematic review and meta-analysis. Nicot Tob Res 2020; 1657-9.
24. Grundy EJ, Suddek T, Filippidis FT, Majeed A, CoroniniCronberg S. Smoking, SARS-CoV-2 and COVID-19: A review of reviews considering implications for public health policy and practice. Tob Induc Dis 2020; 18: 58.

25. Simons D, Shahab L, Brown J, Perski O. The association of smoking status with SARS-CoV-2 infection, hospitalisation and mortality from COVID-19: A living rapid evidence review. Qeios 2020.

26. Saldías F, Díaz O. Cigarette smoking and lower respiratory tract infection. In: Martin-Loeches I (ed). Bronchitis. InTech, 2011. 